\title{
Thoracic adenomegaly as the predominant manifestation of paracoccidioidomycosis
}

Linfadenomegalia torácica como manifestação predominante

de paracoccidioidomicose

Cláudia Yrlanda Simon ${ }^{1}$, Cleudson Nery de Castro ${ }^{1,2}$ and Gustavo Adolfo Sierra Romero ${ }^{1,2}$

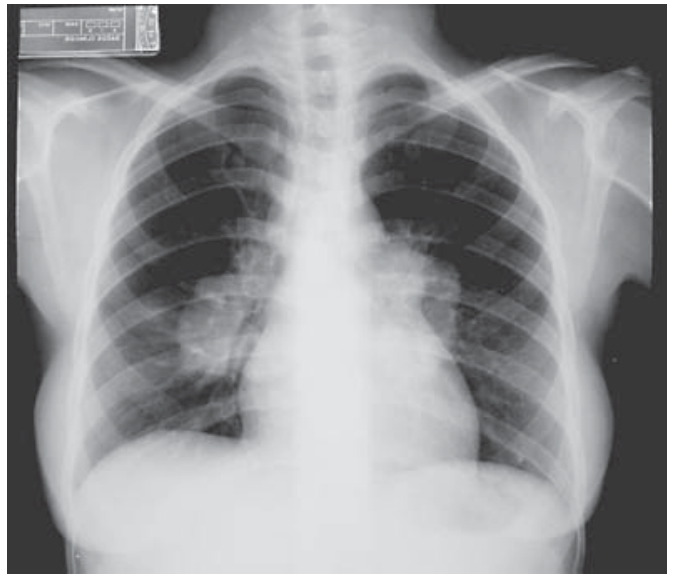

Figure 1 - January 1997.

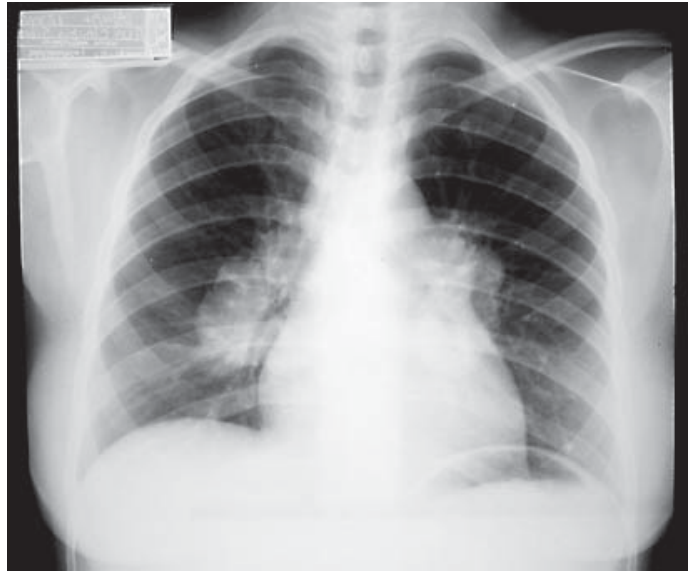

Figure 2 - April 1997.

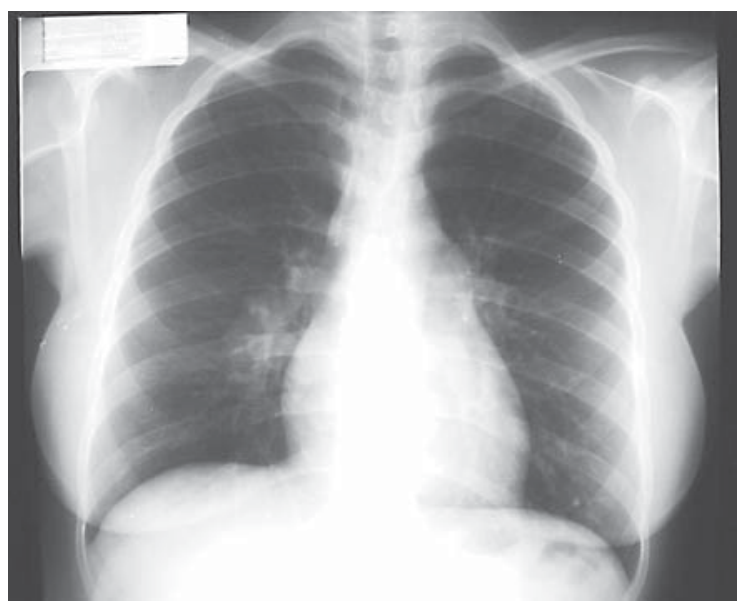

Figure 3 - February 1998.

1. Serviço de Doenças Infecciosas e Parasitárias da Área de Clínica Médica do Hospital Universitário de Brasília, Brasília, DF. 2. Núcleo de Medicina Tropical da Universidade de Brasília, Brasília, DF.

Address to: Prof. Gustavo Romero. Núvleo de Medicina Tropical/UnB. Campus Universitário Darcy Ribeiro, Caixa Postal 04-517, 70919-970 Brasília, DF, Brasil. Tel: 5561 3273-5008; Fax: 5561 3273-2811

e-mail: gromero@unb.br

Recebido para publicação em 9/5/2005

Aceito em 15/6/2005 
A 23 years old woman, from the State of Minas Gerais, Brazil, came to hospital complaining of cervical, axillary and inguinal lymph nodes for the last two months. She also complained of productive cough with white sputum and nocturne fever with weight loss during the last month. She denied dyspnea, urinary or gastrointestinal symptoms. On physical examination she appeared in regular condition, pale, febrile and with rude lung rales. Abnormal painful and hard lymph nodes were detected in cervical, supraclavicular, popliteal, axillary and inguinal chains (1 to $4 \mathrm{~cm}$ diameter). One cervical lymph node had been submitted to biopsy and diagnosed as lymphatic cryptococcosis at the health unit that referred the patient. Abdominal examination was normal. During hospital stay the following laboratory and imaging findings were described: high blood leukocytes, 9.6/g/dl hemoglobin, negative acid-fast bacilli in sputum smears, negative PPD, normal abdominal ultrasound and chest $\mathrm{x}$-rays with hilar dense images (Figure 1). Once paracoccidioidomycosis was suspected, the biopsy was revised confirming Paracoccidioides brasiliensis infection. Serology with immune diffusion technique (ID) revealed positive result for paracoccidioidomycosis and negative for histoplasmosis. She was treated with itraconazol and followed with regularly monthly evaluations. She had satisfactory evolution becoming asymptomatic one month after the introduction of itraconazole therapy, remaining with thoracic adenomegaly until the third month of treatment (Figure 2). Clinical evaluation of respiratory sounds was normal six months later, and peripheral adenomegaly disappeared at the eighth month. After one year of follow-up, treatment was suspended because the patient showed complete remission of signs and symptoms, lowering antibody levels detected by the ID test and remarkable thoracic radiologic improvement (Figure 3). She had the first negative ID test 33 months after treatment interruption. One year later, she stopped the hospital follow-up.

The peculiarities of the reported case are related to the predominant and remarkable involvement of thoracic lymph nodes compared to the less relevant involvement of other lymphatic chains, and the absence of other signs of severe disease and apparently normal lung parenchyma in a post-pubertal woman with excellent response to treatment, all differing from the classical juvenile form of the disease.

A paciente de 23 anos, procedente de Araxá, MG, informava aumento de linfonodos cervicais axilares e inguinais de dois meses de evolução. Associou-se ao quadro tosse com expectoração esbranquiçada e no último mês febre noturna e perda ponderal. Negava dispnéia, queixas urinárias ou gastrointestinais. Ao exame, apresentava-se em regular estado geral, hipocorada, febril e com murmúrio vesicular rude bilateral. Constataram-se linfonodos cervicais, supraclaviculares, poplíteos, axilares e inguinais móveis, endurecidos e dolorosos $(1 \mathrm{a} 4 \mathrm{~cm})$. Um linfonodo cervical tinha sido submetido à biópsia e diagnosticado como criptococose ganglionar no serviço que realizou o encaminhamento. 0 abdome era normal. À internação apresentava leucocitose, hemoglobina de 9,6g/dl, BAAR do escarro e PPD negativos, ecografia abdominal normal e radiografia do tórax com imagens hilares densas (Figura 1). A suspeita de paracoccidioidomicose conduziu à revisão da biópsia, cujo resultado definitivo demonstrou a infecção por Paracoccidiodes brasiliensis. A reação sorológica por imunodifusão dupla em gel (ID) revelou positividade para paracoccidiodomicose com reação negativa para histoplasmose. Recebeu alta hospitalar com prescrição de itraconazol, continuando o acompanhamento ambulatorial mensal. Teve evolução satisfatória, tornando-se assintomática um mês após a introdução do itraconazol, permanecendo com evidência de adenomegalia hilar até o terceiro mês de tratamento (Figura 2). A ausculta respiratória foi normal após seis meses e as adenomegalias desapareceram oito meses depois. Um ano após, finalizou o tratamento com desaparecimento completo dos sinais e sintomas, queda dos títulos de anticorpos na ID e melhora radiológica notável (Figura 3). Apresentou a primeira ID não reagente 33 meses após interrupção do tratamento, recebendo alta do acompanhamento ambulatorial um ano depois.

A peculiaridade da apresentação refere-se ao acometimento linfonodal mais importante e notável na região intratorácica quando comparado com o acometimento das outras cadeias, sem sinais de gravidade e de infiltrados pulmonares relevantes, em uma mulher pós-púbere cuja resposta ao tratamento foi excelente o que difere da apresentação da forma juvenil clássica.

\section{REFERENCES}

1. Blotta MHSL, Mamoni RL, Oliveira SJ, Nouer AS, Papaiordanou PMO, Goveia A, Camargo ZP. Endemic regions of paracoccidioidomycosis in Brazil: a clinical and epidemiological study of 584 cases in the Southeast region. American Journal of Tropical Medicine and Hygiene 61: 390-394, 1999.

2. Paniago AMM, Aguiar JIA, Aguiar ES, Cunha RV, Pereira GROL, Londero AT, Wanke B. Paracoccidiodomicose: estudo clínico e epidemiológico de 422 casos observados no Estado do Mato Grosso do Sul. Revista da Sociedade Brasileira de Medicina Tropical 36: 455-459, 2003.

3. Pereira RM, Bucaretchi F, Barison EM, Hessel G, Tresoldi AT. Paracoccidioidomycosis in children: clinical presentation, follow-up and outcome. Revista do Instituto de Medicina Tropical de São Paulo 46: 127-131, 2004. 